\title{
MORFOLOGI BAHASA ACEH GAMPONG LEUGE PEUREULAK DENGAN GAMPONG KEUDE PEUREULAK TAHUN 2021
}

\author{
Sarmila Devi ${ }^{1^{*}}$ \\ Muhammad Yakob ${ }^{2}$ \\ Desy Irafadillah Effendi ${ }^{3}$ \\ ${ }^{1}$ Program Studi Bahasa Indonesia, FKIP Universitas Samudra \\ ${ }^{2}$ Program Studi Bahasa Indonesia, FKIP Universitas Samudra \\ ${ }^{I}$ Program Studi Bahasa Indonesia, FKIP Universitas Samudra \\ *sarmiladevi835@gmail.com
}

\begin{abstract}
The purpose of this study was to describe the morphology of the Acehnese language contained in the speech of the people of Gampong Leuge Peureulak and Gampong Keude Peureulak. This research is a qualitative research with descriptive type. The method used in this research is the listening method using recording and note-taking techniques. The recorded data is then continued with the recording process. The results of this study are in the form of data descriptions regarding the morphology of the Acehnese language which have been analyzed for their morphological processes, namely affixation and reduplication. The morphological processes found in the Leuge Peureulak village are affixation processes in the form of the prefix ku-, geu-, ta-, ji-, ka-, and pure reduplication, while in the Keude Peureulak village the affixation is ta-, geu-, neu-, ji-, ka-, 1 type of insertion is eum-, and 2 types of reduplication are pure looping and looping with affixes. The morphological process or word formation in the speech of the people of Gampong Keude Peureulak is smoother than the formation of words in the speech of the people of Gampong Leuge Peureulak. Even though due to different factors in the place of residence, speech in daily life should remain subtle so that those who hear are not offended and do not cause misunderstanding.
\end{abstract}

Keywords: Morphology, Acehnese Language, Gampong Leuge, Gampong Keude.

\section{ABSTRAK}

Tujuan Penelitian ini adalah untuk mendeskripsikan morfologi bahasa Aceh yang terdapat pada tuturan masyarakat Gampong Leuge Peureulak dan Gampong Keude Peureulak. Penelitian ini merupakan penelitian kualitatif dengan jenis deskriptif. Metode yang digunakan pada penelitian ini adalah metode simak dengan menggunakan teknik rekam dan tenik catat. Data yang telah direkam kemudian dilanjutkan dengan proses pencatatan. Hasil dari penelitian ini berupa deskripsi data mengenai morfologi bahasa Aceh yang telah dianalisis proses morfologisnya yaitu afiksasi yaitu dan reduplikasi. Proses morfologis yang terdapat pada gampong Leuge Peureulak yaitu proses afiksasi berupa awalan ku-, geu-, ta-, ji-, ka-, dan reduplikasi murni, sementara pada gampong keude peureulak yaitu afiksasi ta-, geu-, neu-, ji-, ka-, 1 macam sisipan yaitu eum-, dan 2 macam reduplikasi yaitu perulangan murni dan perulangan dengan afiks. Proses morfologis atau pembentukan kata pada tuturan masyarakat Gampong Keude Peureulak lebih halus dibandingkan dengan pembentukan kata yang ada dalam tuturan masyarakat Gampong Leuge Peureulak. Meski dikarenakan faktor berbeda tempat tinggal sudah seharusnya tuturan dalam kehidupan sehari-haru harus tetap halus agar yang mendengar tidak tersinggung dan tidak menimbulkan salah paham.

\section{Kata Kunci: Morfologi, Bahasa Aceh, Gampong Leuge, Gampong Keude.}


November 2020

Pendahuluan

Bahasa Aceh merupakan alat komunikasi yang digunakan oleh masyarakat yang bertempat tinggal dalam kawasan Aceh untuk berkomunikasi dengan sesama, bahasa Aceh ini juga sering digunakan oleh etnis Aceh yang berada di luar Aceh. Bahasa Aceh merupakan bahasa dasar atau bahasa ibu yang digunakan dalam kehidupan seharihari masyarakat Aceh.

Ilmu bahasa dalam hubungan sosial kehidupan ataupun kemasyarakatan sangatlah penting, dalam situasi bermasyarakat, seseorang tidak lagi dipandang sebagai individu yang berbeda dan terpisah, tetapi lebih dipandang sebagai kelompok yang bersatu dan sama yaitu sebagai anggota dari kelompok sosial. Bahasa dalam masyarakat tidak hanya digunakan sebagai sarana penyampaian pemikiran dan gagasan melainkan juga digunakan sebagai sarana dalam mengungkapkan hubungan sosial. (Damayanti, 2016:101).

Setiap daerah memiliki khas atau ciri tersendiri dalam bertutur. Masyarakat pesisir pada umumnya dalam berinteraksi dengan sesama masyarakatnya menggunakan berbagai logat bahasa yang kadang sulit untuk kita terima dan tidak semua pendengar akan memaklumi maksud dari tuturan, terkadang ada bahasa yang di tuturkan oleh masyarakat pesisir tersebut sangat kasar dan terkesan menyinggung jika kita dengar, namun bagi masyarakat daerah pesisir penggunaan logat bahasa tersebut biasa saja dan merupakan bahasa yang sudah berterima.

Bahasa Aceh juga mempunyai keunikan tersendiri dalam pemakaiannya, seorang penutur ketika berbicara harus memperhatikan tingkatan-tingkatan dalam berbahasa, tergantung dengan siapa dan dimana ia berbicara, pemakaian bahasa Aceh juga berbeda antara satu daerah dengan daerah lainnya, dan antara satu orang dengan lainnya, tingkatan bahasa
Aceh ini dapat dilihat dari halus dan kasarnya dialek pemakaian seseorang.

Bahasa Aceh juga mempunyai keunikan tersendiri dalam pemakaiannya, seorang penutur ketika berbicara harus memperhatikan tingkatan-tingkatan dalam berbahasa, tergantung dengan siapa dan dimana ia berbicara, pemakaian bahasa Aceh juga berbeda antara satu daerah dengan daerah lainnya, dan antara masyarakat satu orang dengan masyarakat lainnya, tingkatan bahasa Aceh ini dapat dilihat dari halus dan kasarnya dialek pemakaian seseorang. Tingkatan bahasa Aceh ini biasanya juga dapat dilihat dari proses pembentukan atau proses morfologis yang digunakan oleh masingmasing daerah.

Morfologi bahasa merupakan sebuah ilmu yang mengkaji tentang proses pembentukan kata dari suatu bahasa. Morfologi juga diartikan sebagai ilmu yang mengkaji serta memperlajari tentang keseluruhan dari proses pembentukan sebuah kata yang satu sebelum satuan yang membentuk kata tersebut menjadi sebuah kata utuh dan terbentuk menjadi suatu kesatuan kata yang lain yang menimbulkan makna lain (Chaer, 2008:3).

Proses morfologis merupakan sebuah proses pembentukan kata yang akan menghasilkan makna baru. Matthews dalam Septiana (2018:289) mengungkapkan bahwa "Morfologi adalah satu ilmu dalam linguistik yang mempelajari pembentukan kata." Senada dengan hal tersebut, Matthews dalam Septiana (2018:289) mengungkapkan bahwa "Morfologi adalah satu ilmu dalam linguistik yang mempelajari pembentukan kata." Morfologi pada bahasa Aceh juga terdapat 3 macam, yaitu proses pengimbuhan kata yang berupa pembubuhan atau penambahan awalan dan akhiran maupun awalan dan akhiran (Afiksasi), Pengulangan kata dasar (Reduplikasi) dan penyenyawaan (komposisi) (Ali,dkk. 1983:10). 


\section{a. Afiksasi}

Afiksasi merupakan sebuah proses penggabungan morfem menjadi kata yang baru. Afiksasi juga merupakan proses pemberian imbuhan atau proses pengimbuhan pada suatu bentuk kata yang tergolong dalam bentuk asal kata ataupun bentuk dasar (Sulaiman, dkk, 1983:10). Selain itu, Proses afiksasi juga dikatakan sebagai proses penambahan afiks, reduplikasi atau pengulangan kata, dan pemajemukan yang merupakan proses penggabungan dari dua morfem dasar menjadi sebuah kata yang mempunyai makna yang berbeda dengan sebelumnya.

\section{b. Reduplikasi (Perulangan)}

Reduplikasi merupakan pengulangan kata yaitu proses pengulangan bentuk dengan sepenuhnya dari sebuah kata dasar atau seluruhnya maupun pengulangan kata yang hanya sebagian, baik variasi dari fonem-fonem maupun perulangan yang tidak mengakibatkan terbentuknya sebuah kata baru dengan makna yang baru (Ali, dkk, 1983:12).

Gampong atau desa merupakan sebuah tempat sekelompok masyarakat di Aceh tinggal dan menyesuaikan diri dengan sesama masyarakat. Mayoritas masyarakat pesisir yang terdapat di Gampong Leuge Peureulak biasanya berada di warung kopi yang merupakan sebuah tempat untuk bercengkrama serta menggali nformasi-informasi seputar daerahnya maupu daerah luar. Sedangkan masyarakat Keude Peureulak merupakan masyarakat yang tinggal di pertokoan dan pusat perbelanjaan yang mayoritas penduduknya adalah para pedagang.

Penelitian ini bertujuan untuk mengetahui perbedaan antara morfologi bahasa dan mendeskripsikan morfologi bahasa Aceh yang terlihat pada tuturan masyarakat Gampong Leuge Peureulak dengan Gampong Keude Peureulak. Kedua gampong tersebut memiliki mayoritas masyarakat dengan kebiasaan dan lingkungan sosial yang berbeda, tentu saja kedua gampong tersebut memiliki perbedaan tersendiri dalam proses morfologi bahasa yang digunakan dalam berinteraksi sehari-hari.

Penelitian tentang morfologi bahasa juga pernah dilakukan oleh Siti Maryam (2016) yang berjudul Analisis Morfologi Bentuk Pasif Bahasa Jawa Banyumas. Penelitian ini mengkaji tentang imbuhan atau proses morfologi yang berupa prefiks yang tertuju pada penanda pasif yang terdapat dalam tuturan masayarakat Jawa daerah banyumas. Persamaan dengan penelitian ini adalah sama-sama mengkaji mengenai morfologi bahasa, namun perbedaannya adalah penelitian yang dilakukan maryam adalah mengenai morfologi bahasa Jawa dan hanya berfokus pada prefiks penanda pasif yang dapat diterima dalam kalimat.

Selanjutnya penelitian yang dilakukan oleh Mila Sinta, dkk (2019) yang berjudul Analisis Kesalahan Morfologi pada Tuturan Siswa SMPN 3 Banjar. Penelitian ini mengkaji tentang kesalahan dari morfologi bahasa yang merupakan kesalahan pada bentuk afiksasi, kesahalan bentuk reduplikasi dan juga kesalahan komposisi pada tuturan siswa.

Selain itu, Lifatus, dkk (2020) juga melakukan penelitian yang berjudul Interferensi Bahasa Jawa dalam Bahasa Indonesia pada Karangan Bahasa Indonesia Siswa Kelas V UPT SDN 93 Gresik. Penelitian ini mengkaji tentang interferensi bahasa dalam karangan siswa. Berdasarkan hasil penelitian ini ditemukan bentuk interferensi morfologi bahasa jawa dalam aspek afiksasi dan aspek reduplikasi.

Penelitian serupa lainnya juga pernah dilakukan oleh Asmadi (2016) yang berjudul Proses Morfologi pada Kultur Bahasa Etnis Samawa. Penelitian ini mengkaji tentang proses morfologi etnis samawa yang hasilnya berupa afiks 
kultural dan komposisi kultural yang mengandung nilai-nilai budaya seperti hubungan manusia dengan manusia dan hubungan manusisa dengan alam.

Penelitian serupa lainnya juga pernah dilakukan oleh Husni Mubarak (2021) yang berjudul Analisis Morfologi Bahasa Dayak Samihim di Desa Mangka Kecamatan Pamukan Barat Kabupaten Kotabaru. Penelitian ini berfokus pada morfologi yang ada dalam bahasa dayak dan menghasilkan data berupa Prefiks, Sufiks, Infiks serta konfiks yang terdapat pada Bahasa Dayak.

\section{Metodologi Penelitian}

Penelitian ini menggunakan pendekatan kualitatif. Metode penelitian kualitatif atau disebut juga dengan metode penelitian naturalistik karena penelitiannya dilakukan dengan kondisi yang alamiah (natural setting) atau disebut juga dengan metode etnographi, karena awalnya metode penelitian ini lebih banyak digunakan untuk penelitian terkait masalah antropologi budaya maupun sejarah, hasil yang didapat berupa kata-kata berdasarkan objek penelitian(Sugiyono, 2018:8).

Jenis penelitian ini merupakan deskriptif. Penelitian deskriptif. Penelitian ini dikatakan sebagai penelitian sebagai penelitian berjenis deskriptif karena jenis penelitian deskriptif berusaha menjelaskan tentang objek-objek kajian dan peristiwa yang terjadi, selanjutnya dideskripsikan secara sistematis dan akurat mengenai data dan hasil dari data yang dikaji (Nazir, 2011:54).

Penelitian ini dilakukan pada daerah pesisir yaitu di Gampong Leuge Peureulak dan wilayah perkotaan Gampong Keude Peureulak. Sumber data pada penelitian ini adalah masyarakat Gampong Leuge Peureulak dan Gampong Keude Peureulak. Masyarakat yang menjadi sumber data pada penelitian ini disebut informan. Informan yang pada penelitian ini berjumlah 30 orang. 15 orang di ambil dari masyarakat Gampong Leuge Peureulak dan 15 orang lainnya diambil dari Gampong Keude. Penelitian ini dilakukan selama 2 bulan.

Metode yang digunakan pada pengumpulan data dalam penelitian ini adalah metode simak. Metode simak merupakan suatu cara pengumpulan data yang dilakukan dengan cara menyimak penggunaan suatu bahasa, baik itu bahasa lisan maupun bahasa tulis (Azwardi, 2018:161). Metode simak selanjutnya diikuti dengan teknik catat dan rekam.

Penelitian ini menggunakan analisis data kualitatif. Analisis data dilakukan dengan mengorganisasikan data, menjabarkannya dalam unit-unit ,melakukan sintesa dan menyusun kesimpulan (Sugiyono, 2018:244).

a. Data yang terekam disalin ke dalam bentuk teks.

b. Pemilihan data, yaitu memilih data yang akan diteliti morfologisnya.

c. Menganalisis data berdasarkan proses morfologi kata yang ada pada tuturan masyarakat gampong kuala leuge dan masyarakat gampong keude.

\section{Hasil dan Pembahasan}

Berdasarkan penelitian yang telah dilakukan, proses morfologis yang ditemukan pada tuturan kedua gampong tersebut adalah proses afiksasi dan reduplikasi. Berikut hasil yang di dapatkan dari kedua gampong tersebut, yaitu:

\section{A. Analisis Morfologi pada Tuturan Masyarakat Leuge Peureulak}

\section{Afiksasi}

Prefiks (awalan ku-)

(1) Nama Informan : Anita

Hari dan Tanggal: Rabu, 20-01-2021

Tempat : Kios jajanan

\section{AN : Inengnyan meunyôe $\underline{k u e u}$ jicokpeng}

Perempuan itu kalau aku lihat ia ambil duite 


\section{MY : Adek geubijih jicok}

„Adik diberi uangnya, dia ambil sendirie

Percakapan ini berlangsung di sebuah kios kecil dengan suasana informan atau penutur sedang marah. Beliau menuturkan bahasa yang terdengar kasar. Imbuhan yang terdapat pada tuturan informan ini adalah kata $\mathrm{ku} e u$. Awalan yang digunakan adalah $k u$ - yang merupakan kata ganti orang kesatu tunggal yaitu $k u+e u=k u e u$. Kata $\mathrm{ku}$ eu memang sering digunakan jika hanya berbicara dengan orang sebaya ataupun anak-anak, namun penggunaan inengnyan sebagai subjek terkesan menjadi kasar jika dituturkan, tuturan ini terdengar tidak bagus.

\section{Prefiks (Awalan) Geu-}

(2) Nama Informan : Syarwani

Hari dan Tanggal: Minggu, 24-01-2021

Tempat : Rangkang Sawah

SW : Lheuh suboh ka_geubuka raseuki „Usai subuh sudah Dia (Allah) buka rezeeki

MI : Han tajak taduk manteng pané mungken itameng raseuki „Tidak dicari duduk saja mana mungkin dating rezekiee

Percakapan ini berlangsung di rangkang sawah pada siang hari, para petani sedang berkumpul dengan beberapa pemuda. Kata yang diteliti pengimbuhan pada tuturan ini adalah geubuka yaitu geu+buka = geubuka. Awalan yang digunakan penutur atau informan adalah geu- yang merupakan kata ganti orang ketiga tunggal dan jamak. Awalan geu- pada tuturan ini terdengar bagus dan sopan, terlebih geu- yang dimaksud dalam tuturan ini adalah penyebutan untuk Allah swt. Tuturan ini bagus untuk digunakan.
3. Prefiks (Awalan) ta-

(3) Nama Informan : Mustafa

Hari dan Tanggal: Selasa, 12-01-2021

Tempat : Warung Kopi

$$
\begin{aligned}
& \text { MT } \text { :Tinggai taculok silang } \\
& \text { „Tinggal kita masukkan selange } \\
& \text { NP : Nye } \\
& \text { „Iya“ }
\end{aligned}
$$

Percakapan ini berlangsung di warung kopi pada malam hari, para petani sedang membahas tentang perkembangan sawah. Kata yang dianalisis pengimbuhan pada tuturan ini adalah taculok. Awalan yang digunakan adalah ta- yang merupakan kata ganti orang kesatu jamak yaitu ta+culok= taculok. Awalan ta- ini digunakan untuk menyatakan diri sendiri dan temanteman, awalan $t a$ - dapat diartikan secara bersama, artinya bukan hanya penutur sendiri, namun penggunaan kata culok pada tuturan ini terdengar kasar dan bagus jika diganti dengan pasoe.

\section{Prefiks (Awalan) ji-}

(4) Nama Informan : Maryana

Hari dan Tanggal: Rabu, 20-01-2021

Tempat : Kios Jajanan

\section{MY : Kop teuga jicok pèng}

„Cukup sering dia ambil uangee

\section{AN: Angkeuh jicok jih pèng}

„Itulah, dia ambil uang"

Percakapan ini berlangsung di sebuah kios kecil ketika seorang ibu sedang memarahi anaknya. Kata yang dianalisis pengimbuhannya adalah jicok. Awalan yang digunakan pada kata tersebut adalah $j i$ yang merupakan kata ganti orang ketiga 
tunggal dan jamak yaitu $j i+c o k=j i c o k$, kata ganti ji- ini umum dikatakan di daerah lain. Penggunaan awalan ji- harus disesuaikan untuk menyebutkan orang yang lebih tua atau lebih muda.

\section{Prefiks (Awalan) $k a-$.}

(5) Nama Informan : M. Yacob Usman

Hari dan Tanggal : Senin, 25-01-2021

Tempat : Pos pemuda

\section{MY : Kah puta kapeulaku nyan}

„Apa yang kamu lakukan itue

SR : Hana pu karu ikah

„Tidak usah rebut kamu“

Percakapan ini berlangsung di pos perkumpulan pemuda di malam hari. Kata yang dianalisis pengimbuhan pada tuturan ini adalah kapeulaku. Awalan yang digunakan pada kata tersebut adalah $k a$ - yang merupakan kata ganti orang kedua tunggal dan jamak yaitu $k a+$ peulaku=kapeulaku. Awalan $k a-$ wajar digunakan untuk berkomunikasi dengan teman sebaya, tidak terkesan kasar maupun halus, namun kata kapeulaku biasanya jarang digunakan untuk berbicara dengan sesama, kata tersebut terkesan kurang sopan. Kata kapeulaku lebih bagus jika diganti dengan kata kapeugot.

\section{Reduplikasi}

1. Perulangan utuh (murni)

(1)Nama Informan : Syarwani

Hari dan Tanggal: Minggu, 24-012021

Tempat : Rangkang Sawah

SW : sama-sama keunông nyan dua $\underline{k u h}$ „sama-sama kena penyakit itu kami berdua"

MI : o, pue roeh

$$
\text { „o, begitu }
$$

Percakapan ini juga berlangsung di rangkang sawah saat para petani sedang beristirahat dan beberapa pemuda juga ikut bersantai disana. kata yang mengalami perulangan pada tuturan ini adalah samasama. Kata ini merupakan perulangan murni atau utuh karena kata yang diulang tetap sama, kata yang diulang pada tuturan ini tidak diikuti dengan afiks. Perulangan ini tidak kasar dan tidak halus, terdengar biasa saja dan umum.

\section{Analisis Morfologi pada Tuturan}

\section{Masyarakat Keude Peureulak}

\section{Afiksasi}

1. Prefiks (Awalan) ta-

(1) Nama Informan : Nurjannah

Hari dan Tanggal : Selasa, 12-01-2021

Tempat : Toko baju

\section{NJ: Yang nyan tabloe aséng} "Yang itu kita beli asing"e

\section{KJ : Puta ikheun, serum koen „Apa namanya, serum kan}

Percakapan ini berlangsung di toko baju, mayoritas penduduk gampong Keude Peureulak rumahnya berbentuk. Ibu-ibu sedang mampir sebentar membahas tentang kosmetik keluaran terbaru. Awalan yang digunakan adalah ta- yang merupakan kata ganti orang kesatu jamak yaitu ta+bloe $=$ tabloe, kata tersebut umum terdengar sopan dan enak di dengar karena umum dan pantas digunakan dalam berbicara meskipun hanya tertuju umtuk diri sendiri namun tetap menggunakan $t a$ Penyebutan $t a$ - dipakai karena bermakna kita. 
November 2020

2. Prefiks (Awalan) Geu-

(2) Nama Informan : Muzakir

Hari dan Tanggal: Senin, 18-01-2021

Tempat : Toko Emas

$\mathrm{MZ}$ : Bôh pané geutém teuma

'Mana dia mau'

AW : Kajipeugah awak rantoe panyang

„Sudah dibilang orang rantau panjang"

Percakapan ini juga berlangsung di toko emas yaitu rumah penduduk Gampong Keude, para memuda masih membahas mengenai calon tunangan. Kata yang mengalami pengimbuhan adalah geutém yaitu geu+tém = geutém. Awalan geu- yang merupakan kata ganti orang ketiga tunggal dan jamak. Penutur menyebutkan oranglain dengan menggunakan geu- yang artinya dia namun pemahaman katanya diartikan sebagai beliau. Penutur menghormati dan menuaan sebutan untuk orang yang dituju, awalan tersebut dianggap sopan dan bagus untuk digunakan dalam brtkomunikasi seharihari.

(3) Prefiks (Awalan) Geu-

(3) Nama Informan : Nurjannah

Hari dan Tanggal : Senin, 12-01-2021

Tempat : Toko Baju

NJ : Pat neupeugot rumôh

„Dimana anda bangun rumah

SH : Kalheuh rumôh euh

„Sudah selesai rumahnya ya"

Percakapan ini berlangsung di toko baju yaitu salah satu rumah penduduk, Ibuibu sedang mengobrol. Kata yang dianalisi pengimbuhan pada tuturan ini yaitu peugot yang menggunakan awalan neu- yang merupakan kata ganti orang kedua tunggal dan jamak yaitu neu+peugot=neupeugot .
Tuturan dengan kata ganti neu- terdengar sopan dan halus untuk berbicara dengan orang yang lebih tua maupun yang lebih muda, seperti pada tuturan ini meskipun usia mereka berbeda namun dalam bertutur tetap sama-sama sopan.

4. Prefiks (Awalan) ji-

(4) Nama Informan : Jasmiati

Hari dan Tanggal: Sabtu, 16-01-2021

Tempat : Toko Perabot

JM : Hana jijak keureija

Dia tidak pergi kerja"e

SH : Hanjeut jitren kadang

Dia tidak bisa turun mungkin ${ }^{\text {ee }}$

Percakapan ini juga berlangsung di toko perabot. Kata yang dianalisis pengimbuhan pada tuturan ini adalah jijak. Awalan yang digunakan pada kata tersebut adalah $j i-$ yang merupakan kata ganti orang ketiga tunggal dan jamak yaitu $j i+j a k=j i j a k$, kata ganti $j i$ - ini umum dikatakan di daerah lain, penggunaan awalan $j i$ - harus dibedakan untuk menyebutkan yang lebih tua atau muda. jika orang tersebut lebih tua maka harus menggunakan geu-.

5. Prefiks (Awalan) ka-

(5) Nama Informan : Muhammad Abral

Hari dan Tanggal : Senin, 18-01-2021

Tempat : Toko Emas

MA : Hoe kajak Lah

„Kemana kamu pergi, Lahe

FT : Yak nonton bola

„Mau nonton bola"

Percakapan ini berlangsung di toko emas, rumah salah satu pemuda gampong keude peureulak, para pemuda sering 
berkumpul di sore hari karena jarak rumah mereka tidak berjauhan. Kata yang dianalisis pengimbuhan pada tuturan ini adalah kajak. Awalan yang digunakan pada kata tersebut adalah ka- yang merupakan kata ganti orang kedua tunggal dan jamak yaitu $k a+j a k=k a j a k$. Tuturan tersebut digunakan saat berbicara dengan teman sebaya, hanya saja akan lebih terdengar bagus dan lembut jika disebutkan neujak.

\section{Infiks (sisipan) eum-}

(6) Nama Informan : Maulina

Hari dan Tanggal : Rabu, 13-01-2021

Tempat : Toko Perabot

ML : Hek ceumakoe lagèe nyôe

„Lelah membujuk seperti iniee

\section{HD :Hanjeut tabi}

„Tidak bisa kita kasih

Percakapan ini berlangsung di toko perabot. Ibu-ibu sedang berkumpul melihat-lihat seprai yang dibawa penjual angsuran. Kata yang dianalisi pengimbuhan yang berupa sisipan pada tuturan ini adalah ceumakoe yang dari kata dasarnya yaitu cakoe +eum= ceumakoe. Sisipan eum- mengartikan pekerjaan yang sedang dilakukan atau diterjemahkan dengan membujuk, jika dalam bahasa Indonesia sama dengan menggunakan awalam me- Sisipan yang ada pada tuturan ini biasa digunakan oleh masyarakat dan tidak kasar .

\section{Reduplikasi}

1. Perulangan utuh

(1) Nama Informan : Nuraida

Hari dan Tanggal : Selasa, 12-01-2021

Tempat : : Toko Perabot
ND : Nyan pih sipatu lagak-lagak hinan

'Sepatu cantik-cantik disana'

\section{HD : Nyankeuh lageenyan sit bak jih}

„Sama, begitu juga dengan diace

Percakapan ini berlangsung di toko perabot. Ibu-ibu sedang membahas tentang sepatu yang di jua di toko-toko sekitar mereka. Kata yang mengalami perulangan pada tuturan tersebut adalah kata galakgalak. Kata tersebut merupakan perulangan utuh yang juga bermakna sama tidak ada yang berubah dan tidak ditambahi afiks. Kata ini biasa digunakan dan umum terdapat dalam tuturan masyarakat.

\section{Simpulan dan Saran}

Berdasarkan hasil penelitian dan pembahasan yang telah dipaparkan, maka dapat disimpulkan bahwa proses morfologis yang terdapat pada tuturan bahasa Aceh sama dengan proses morfologis pada bahasa indonesia.

Dari hasil penelitian didapatkan bahwa proses morfologis atau pembentukan kata pada tuturan masyarakat Gampong Keude Peureulak lebih halus dibandingkan dengan pembentukan kata yang ada dalam tuturan masyarakat Gampong Leuge Peureulak.

Adapun morfologi yang terdapat pada setiap tuturan masyarakat leuge peureulak adalah 5 macam yaitu awalan $\mathrm{ku}$-, geu-, ta, ji-, ka-, 1 macam akhiran yaitu $k u h$-, dan 1 reduplikasi murni. Sedangkan pada masayarakat Gampong Keude Peureulak juga terdapat 5 macam awalan yaitu awalan ta-, geu-, neu-, ji-, ka-, 1 macam sisipan yaitu eum-, dan 2 macam reduplikasi yaitu perulangan murni dan perulangan dengan afiks. 
November 2020

Berdasarkan simpulan yang telah

dipaparkan, peneliti mengajukan beberapa saran, antara lain:

(1) Kepada masyarakat Gampong Leuge Peureulak agar dapat merubah pola penuturan yang lebih baik lagi, agar bahasa Aceh yang didengar oleh yang mendengarnya merasa nyaman.

(2) Kepada masyarakat Gampong Keude Peureulak agar dapat senantiasa menjaga penuturan bahasa yang baik lagi dalam proses jual beli yang biasa mereka lakukan. 


\section{DAFTAR REFERENSI}

Ali, Zaini, dkk. 1983. Sistem Morfologi Kata Kerja Bahasa Aceh. Jakarta: Pusat

Azwardi. 2018. Metode Peneitian Bahasa dan Sastra Indonesia. Banda Aceh: Syiah Kuala University Press.

Nazir, Moh. 2011. Metode Penelitian. Darussalam: Ghalia Indonesia.

Septiana, Dwiani. 2018. Proses Morfologis Verba Bahasa Waringin (Morphological Process of Verb in Waringin Language). Vol 14, No 2. Hal 287-302. Diperoleh pada 02 Januari 2021 dari ojs.badanbahasa.kemendikbud.go.id.

Sugiyono. 2018. Metode Penelitian Kuantitatif, Kualitatif, dan dan R\& D. Bandung: Alfabeta.

Sulaiman, Budiman, dkk. 1983. Struktur Bahasa Aceh: Morfologi dan Sintaksis. Jakarta: Pusat pembinaan dan pengembangan bahasa departemen pendidikan dan kebudayaan.

Sulaiman, Nasruddin, dkk. 1992. Aceh Manusia Masyarakat Adat dan Budaya. Banda Aceh: Pusat Dokumentasi dan Informasi Aceh. 